\title{
EDUCATIONAL REQUIREMENTS FOR A CAREER IN AIRLINE MANAGEMENT: AN INDUSTRY PERSPECTIVE
}

\author{
Robert W. Kaps and José R. Ruiz \\ Southern Illinois University
}

\begin{abstract}
Presidents at thirty of the top United States airlines were asked to indicate what educational preparation they felt students seeking a career in airline management should possess. They were asked to rate 18 courses offered in the Aviation Management baccalaureate degree curriculum at Southern Illinois University at Carbondale. They were also asked to rank 14 suggested courses from the Council on Aviation Accreditation (CAA) Curriculum Guideline. Following analysis, courses were placed in three categories: Inclusionary, Exclusionary and Uncertain/Diverse.

Findings indicate that airline presidents place the greatest value on courses stressing fiscal requirements, legal aspects, airline operations and operating in a global environment. Conversely, courses including Applications of Technical Information, The National Airspace System, Airport Planning, Airport Management, Professional Development and General Aviation Operations were ranked low in importance.
\end{abstract}

\section{Introduction}

The aviation industry has evolved into a complex enterprise (Adamski \& Doyle, 1993). Coincidentally, aviation education programs (Johnson \& Lehrer, 1995) now exist in many technical schools, colleges, and universities throughout the United States. Bachelor degree programs in aviation are offered by scores of large universities. In recent years, baccalaureate and graduate programs have been established to meet increasing demands of industry and government. Despite proliferation of undergraduate aviation programs and a growing number of graduate degrees in areas of aviation, but for a course offered in graduate airline education (Concordia, 1993), there seems to be no established program directed toward the needs of the educational requirements for a career in airline management.

Emerging global market dynamics have caused the aviation industry to elevate entrylevel employment qualifications for both engineering and non-engineering personnel. Many employers require degrees in addition to aviation certification for entry level positions. So pervasive has this demand become in recent years that $94 \%$ of new hire pilots employed by major and national airlines hold baccalaureate or higher degrees. Certification alone was deemed sufficient for most positions only a few years ago. For many aviation related positions, employers prefer business knowledge and training, language and communications skills, and fundamental knowledge and understanding of the broader socio-economic global system of which the aviation industry is a major element (Kaps, 1995).

Profound changes are taking place in the aviation industry. Privatization, globalization and liberalization in the form of reduced government regulation are placing challenging demands on industry managers as they strive for improved productivity, quality and profitability. This new market environment, coupled with massive financial losses, has forced air carriers to re-define core business objectives and reshape work forces to reflect and support these objectives. A survey (Johnson \& Lehrer, 1995) conducted among collegiate aviation educators to define curricular subject matter in aeronautical/aerospace programs indicated a strong need to present business and business related subjects. 


\section{Statement of the Problem}

Preliminary research indicates there is no body of literature that addresses specific educational requirements for a career in airline management.

\section{Methodology}

In an attempt to define airline curricular necessities, curricular components of an established and functional aviation undergraduate program and guidelines promulgated by the University Aviation Association accrediting body were used as the established range. To facilitate this goal a two part research method was established. This consisted of a two part Delphi survey coupled with replicated statistical investigation of curriculum components.

\section{Survey Format}

The objective of Delphi technique is to obtain consensus opinions without bringing individuals together in face to face meetings. This is achieved by a series of questionnaires interspersed with controlled opinion feedback.

There are three Delphi forms generally used in an educational setting. The first, the Normative or Consensus Delphi, is designed to gather expert opinion of specified issues from a defined group of experts. Exploratory Delphi is a method of eliciting expert opinions about the probability, desirability and impact of future events. The third is the Focus Delphi which gathers opinions from diverse groups that will be affected by a projected program or policy.

The Delphi Technique is considered a quasi-qualitative research method (Rojewski, 1990). Delphi has been consistently employed to gather expert opinion and thought on how higher education can improve education programs. The Delphi technique is an applicable tool for educational research and curriculum development (Volk, 1993). The Delphi process is a method of achieving statistically derived group consensus, forecasting, or problem solving by having a group complete a series of questionnaires (Helmer, 1966).

\section{Questionnaire Design}

The questionnaire was composed of two distinct parts. Part I consisted of the eighteen curriculum statements relating to specific aviation management courses offered by Southern Illinois University at Carbondale (SIUC). Each statement defining the specificity of the particular course, was followed by a ranking mechanism. Thus, each statement contained a curriculum component title, brief course description and a Likert scale.

Identical in design as Part I, Part II contained fourteen generic courses recommended by the Council on Aviation Accreditation (CAA) for an aviation management curriculum. Since these course titles contain no indication of content by the CAA, a possibility of overlap and duplication to Part I may exist. Respondents were thus asked to evaluate courses presented in Part I and Part II independently. The CAA guidelines are not intended for an Airline Management curriculum and are therefore purposely generic.

The Likert scale used in this study represented degrees of importance assigned to the eighteen SIUC curriculum statements and the CAA aviation guidelines. The Likert scale was used to allow respondents to indicate the extent to which they believed curriculum statements 
were important to a career in airline management. The Likert scale was selected because of simplicity and ease of use.

Respondents were instructed to rank the importance of each curriculum statement using a five point Likert scale. The questionnaire contained no open-ended questions that allowed respondents to justify or elaborate their rankings. Kaufman and English (1979) suggested that a prepared list of items may erode the creativity, however, a prepared list does provide comprehensive data when validated by expert opinion.

The following are descriptions of the 18 SIUC Aviation Management courses cited in this study (SIUC Undergraduate Catalog, 1995):

Work Center Management. A study of the problems of managing a small working unit (division, department, work center, section, etc.) within a larger unit (agency, company, regional office, etc.) Included items will be work center goals identification, staffing needs, monitoring of work process reporting, work center communications, and interpersonal relations within the work center.

Applications of Technical Information. This course is designed to increase student competence in analyzing and utilizing the various types of technical information encountered by managers in technical fields.

Labor-Management Problems/Aviation Labor Relations. Students will gain a general understanding of the economic situation of which labor-management problems represent a subset. They will develop a perspective on the evolution of labor relations in the United States economy and on how the interaction of labor and management differs throughout the world. The collective bargaining section introduces the student to the techniques of bargaining used by labor and management in their ongoing interactions.

Data Interpretation. A course designed for students beginning their major program of study to examine data use in their respective professions. Emphasis will be placed upon an understanding of the basic principles and techniques involved with analysis, synthesis, and utilization of data.

Professional Development. Introduces students to the various elements involved in obtaining a position in their chosen career field. Topics included are: personal inventories, placement services, employment agencies, interviewing techniques, resumes, letters of application, references, and employment tests. Each student will develop a portfolio including personal and professional information related to individual career goals.

The Air Traffic Control System, Procedures and Rules.. This course provides instruction in basic air traffic control procedures and phraseology used by personnel providing air traffic control services. Students will become familiar with Federal Aviation Administration handbook and federai aviation regulations that pertain to the operational responsibilities of an air traffic controller.

Airport Planning. To acquaint the student with the basic concepts of airport planning and construction, as well as an investigation of various regulatory agencies in the industry and their functions.

Aviation Industry Regulations. A study of various regulatory agencies of the industry and their functions. 
Airport Management. A study of the operation of an airport devoted to the phases of lighting, fuel systems, field marking, field buildings, hangars, and surrounding community.

Airline Management. A study of the administrative aspects of airline operation and management including a detailed study of airline organizational structure.

General Aviation Operations. A study of general aviation operations including fixed base operations (fuel, sales, flight training, charter, etc.), corporate aviation (business aviation, corporate flight departments, executive air fleets, etc.) and the general aviation aircraft manufacturing industry.

Legal Aspects of Aviation. The student will develop an awareness of air transportation. The course will emphasize basic law as it relates to contracts, personnel, liabilities, and legal authority of governmental units and agencies.

Aviation Maintenance Management. To familiarize the student with the functions and responsibilities of the aviation maintenance manager. Maintenance management at the fixed based operator, commuter/regional airline, and national carrier levels will be studied.

Aviation Safety Management. This course will survey the various aspects of aviation flight and ground safety management. Weather, air traffic control, mechanical and human factors in aviation safety management will be reviewed.

Fiscal Aspects of Aviation Management. An introduction to the fiscal problems encountered in the administration of aviation facilities and airline operations.

Current Issues in Aviation Management. A review of current problems affecting the aviation industry with particular emphasis on resource allocation, planning, and internal and external constraints.

National Airspace System. This course provides instruction on the national airspace system, its purpose and major components. It defines the Federal Aviation Administration's role in the operation, maintenance and planning of the national airspace system.

Aviation Occupational Internships. Each students will be assigned to a departmentally approved work site engaged in activities related to the student's academic program and career objectives. The student will be assigned to an unpaid internship position and will perform duties and services in an instructional setting as previously arranged with the sponsoring work site supervisor. (pp. $104 \& 105,151$ \& 152)

The following 14 courses utilized in this study were derived from the 1990 CAA aviation management guidelines and at that time were solely identified by title without description.

\begin{tabular}{|lll|}
\hline Accounting & Aviation Legislation & Macroeconomics \\
Air Cargo & Business Law & Management I \& II \\
Air Transportation & Data Interpretation & Marketing \\
Airport Management & International Aviation & Microeconomics \\
Aviation History & General Aviation Management. & \\
\hline
\end{tabular}

Note. 1990 CAA Aviation Management Guidelines. 


\section{Questionnaire Validity}

The questionnaire was tested by three aviation educators for content validity, clarity of instructions and research focus. This method followed the procedure outlined by Ary (1985) to:

...have competent colleagues familiar with the purpose examine the items to judge whether they are adequate for measuring what they are supposed to measure and.... whether they are a representative sample of the behavior domain under investigation. (p. 357)

Primary concern in the development of the questionnaire centered on consistency of interpretation of all terms used, document format and style. According to Best and Kahn (1986), the meaning of all terms must be clearly defined so that they have the same meaning to all respondents.

\section{Selection of Interviewees}

Thirty airline presidents were identified to request assistance in completing the developed questionnaire. Airline president identification was obtained from the World Aviation Directory (1994), which lists corporate members of each aviation and airline company. The criterion selected to determine the top thirty airlines for the purpose of this study was the totality of annual revenue passenger miles (RPMs).

Airline presidents were selected as the focus group to maintain a level of airline expertise. Balaraman and Venkatakrishnan (1980) stated,"when evaluating or investigating professional curricula, a panel must be drawn from those in similar professions." Leide (1977) wrote that the selection of experts should have as its major consideration "their professional competence" (p.171). Because of their background and responsibility, the identified executives are sensitive to career advancement associated with the airline industry. This is consistent with Dalky's (1972) views for expert identification and with Pratt (1980) who wrote:

The experts whose assessment of the curriculum is sought need to be knowledgeable.... be willing and encouraged to deliver a candid judgment....There is something to be said for having an assessment by disciplinary experts and curricular generalists. (p. 410)

\section{Data Collection}

Questionnaires were distributed in April 1995 to the thirty identified presidents of those United States airlines having recorded the highest revenue passenger miles. Twenty four usable surveys were returned. Each questionnaire contained a unique tracking number to allow the researchers to correctly identify respondents. The respondents were requested to complete the survey instrument using the following possible responses:
$\frac{1}{N o t}$
$\stackrel{2}{\text { Vaguely }}$
Important
$\underline{3}$
Somewhat
$\underline{4}$
Important
Important
very
Important

A sixth category, "Don't Know", was included should the respondent be unable or choose not to rank a curriculum statement. Likert scales were used to allow the airline 
executives to indicate the extent to which they believed a statement was important for a career in airline management. Data from the twenty-four respondents were gathered, and means and standard deviations were calculated.

Each respondent was contacted, over a four month period of time, to determine if they would once again respond to the same questionnaire, in light of the consensus which had developed. Each, either personally, or through their administrative staff, responded in the affirmative.

\section{Survey 2}

Distribution of the second questionnaire was accomplished in March 1996 in the same manner as the previous questionnaire. This questionnaire contained the original curriculum statements and Likert scale. Each participant's original ranking for each curriculum statement was superimposed for each of the eighteen SIUC curriculum statements and the fourteen generic CAA guidelines. In addition, the group's mean for each question was indicated on the questionnaire.

The twenty-four airline executives were requested to compare their previous individual responses with the mean responses generated by the original survey. Participants were asked to review their initial responses in keeping with the following instructions:

1. Read each Part I and Part II curriculum identifier, noting the original grouped mean and your superimposed individual rating from the original response.

2. Re-evaluate the original response in light of the emerging consensus (group mean) and,

a. circle your superimposed original rating if your individual response has not changed.

b. circle the group mean score if agreement exists with the group consensus.

c. re-evaluate and circle another of the five choices

Upon receipt of all twenty-four responses, data were evaluated and means and standard deviations were calculated.

\section{Treatment of Survey Data}

Survey 1 and Survey 2 responses were collapsed and analyzed as grouped mean ratings. Each curriculum statement was evaluated for consensus among respondents.

\section{Consensus}

To measure levels of consensus, mean scores were analyzed. Mean responses ranging from 4.0 to 5.0 (important to very important) were perceived as strong support for inclusion in an airline curriculum. Mean responses ranging from 2.50 to 1.00 (vaguely important to not important) were perceived as strong indications for exclusion as an educational requirement. Mean responses ranging between 2.51 and 3.99 were considered as too vague, or, not definitive enough to be considered for inclusion in an airline curriculum. Clasen and Dormody (1994) indicated that the discrete ordinal nature of each Likert scale point permits summarization of responses as counts, percentages or categories. Likert (1932) indicated that he never intended for the five point response alternatives to be the scale. Thus, 
categorization permitted blending of like or similar responses and splitting the "Somewhat Important" category scores above and below the mean.

\section{Stability}

Stability was determined by two methods. The first consisted of percentage change in mean responses between the first and second survey results. Dajani, Sincoff and Talley (1979) stated that "consensus is assumed to have been achieved when a certain percentage of the responses fall within a prescribed range" (p. 83). Miller (1970) and Dajani, et al.(1979) indicated that a change of less than $15 \%$ was an indication of stability.

The second measure of stability compared the grouped standard deviations between the first survey and second survey. A decrease in standard deviation was a reliable indicator of stability and movement toward consensus. The standard deviation which is the square root of the variance, satisfies this criterion.

\section{Analysis of Data}

Eighteen curriculum components presently in use in the SIUC Aviation Management Program and fourteen CAA suggested aviation components were utilized as survey material to define educational requirements for a career in airline management. To determine and validate consensus towards inclusion of such items for a career in airline management, a second Delphi questionnaire was sent to airline presidents following analysis of the first survey.

Completion of the Delphi survey provides consensus relationships among different categories of curriculum. Based on standard deviation and mean observance, results fell into three distinct categories. These consisted of those statements having high consensus for inclusion as educational requirements for a career in airline management (Inclusionary Curriculum Statements), high consensus for not including subject matter (Exclusionary Curriculum Statements), and those where either support or lack of support was questionable (Uncertain/Diverse Curriculum Statements).

\section{Analysis of Airline Respondent Rated SIUC Curriculum}

\section{Consensus Stability}

Analysis of industry respondent mean stability indicated three curriculum statements with Survey 2 ratings identical to Survey 1 ratings. Those curriculum statements were Airport Management, Application of Technical Information and Aviation Labor Relations. The highest percentage change, Basic Air Traffic Control, experienced a shift of $+10.50 \%$, while Current Issues in Aviation Management moved $+7.32 \%$.

Fourteen of the eighteen curriculum statements, or $77.78 \%$, indicated increased Survey 2 means. Three (16.67\%) experienced no change and only one $(5.55 \%)$ indicated a decreased mean. The average percentage change for all curriculum statements from Survey 1 to Survey 2 was $+2.97 \%$. This aggregate percentage change, and each individual variation, were well within the predetermined $15 \%$ stability level. Thus, mean stability was achieved within the industry respondents. Table 1 indicates mean stability ratings for industry respondents. 
Table 1

Airline Executive Mean Comparisons of SIUC Aviation Management Courses in Undergraduate Catalog

\begin{tabular}{|l|c|c|c|}
\hline \multicolumn{1}{|c|}{ Topic } & Survey I & Survey II & $\%$ \\
\hline Airline Management & Mean & Mean & Change \\
\hline Airport Management & 4.636 & 4.724 & $1.96 \%$ \\
\hline Airport Planning & 3.364 & 3.364 & $0.00 \%$ \\
\hline Application of Technical Info. & 2.545 & 2.455 & $3.54 \%$ \\
\hline Aviation Industry Regulations & 2.636 & 2.636 & $0.00 \%$ \\
\hline Aviation Labor Relations & 4.273 & 4.364 & $2.13 \%$ \\
\hline Aviation Maintenance & 4.455 & 4.455 & $0.00 \%$ \\
\hline Management & 4.364 & 4.455 & $2.09 \%$ \\
\hline Aviation Safety Management & 4.182 & 4.273 & $2.18 \%$ \\
\hline Basic Air Traffic Control & 3.455 & 3.818 & $10.50 \%$ \\
\hline $\begin{array}{l}\text { Current Issues in Aviation } \\
\text { Management }\end{array}$ & 3.727 & 4.000 & $7.32 \%$ \\
\hline Data Interpretation & 3.909 & 4.000 & $2.33 \%$ \\
\hline Fiscal Aspects of Aviation & 4.091 & 4.273 & $4.45 \%$ \\
\hline General Aviation Operations & 2.019 & 2.107 & $0.77 \%$ \\
\hline Internship & 3.364 & 4.091 & $2.16 \%$ \\
\hline Legal Aspects of Aviation & 4.182 & 4.364 & $4.35 \%$ \\
\hline National Airspace System & 1.818 & 1.893 & $4.13 \%$ \\
\hline Professional Development & 2.818 & 2.909 & $3.23 \%$ \\
\hline Work Center Management & 3.909 & 4.000 & $2.33 \%$ \\
\hline
\end{tabular}

Analysis of industry respondents standard deviations, Table 2 , indicates five curriculum statements with no standard deviation movement between Survey 1 and Survey 2. These were Airport Management, Airport Planning, Application of Technical Information, Aviation Labor Relations and National Airspace System. The largest change in standard deviation occurred with Fiscal Aspects of Aviation where a change of $(-.316)$ was experienced. Other curriculum statements with large changes in standard deviation were Basic Air Traffic Control (.285), Data Interpretation (-.258) and Legal Aspects of Aviation (-.246). The average standard deviation for the curriculum statements decreased from (.808) in Survey 1 to $(.688)$ in Survey 2 , a decrease of $(-.120)$. 
Table 2

Airline Executive Deviation Comparisons of SIUC Aviation Management Courses in Undergraduate Catalog

\begin{tabular}{|l|c|c|c|}
\hline \multicolumn{1}{|c|}{ Topic } & Survey I & Survey II & \\
\hline Airline Management & Std. Dev & $\underline{\text { Std. Dev }}$ & Difference \\
\hline Airport Management & 0.751 & 0.647 & -0.104 \\
\hline Airport Planning & 1.120 & 1.120 & 0.000 \\
\hline Application of Technical Info. & 0.688 & 0.688 & 0.000 \\
\hline Aviation Industry Regulations & 0.809 & 0.809 & 0.000 \\
\hline Aviation Labor Relations & 0.604 & 0.505 & -0.099 \\
\hline Aviation Maintenance & 0.522 & 0.522 & 0.000 \\
\hline Management & 0.674 & 0.522 & -0.152 \\
\hline Aviation Safety Management & 0.751 & 0.647 & -0.104 \\
\hline Basic Air Traffic Control & 1.036 & 0.751 & 0.285 \\
\hline Current Issues in Aviation & 0.505 & 0.467 & -0.038 \\
Management & & & \\
\hline Data Interpretation & 1.044 & 0.786 & -0.258 \\
\hline Fiscal Aspects of Aviation & 1.221 & 0.905 & -0.316 \\
\hline General Aviation Operations & 0.701 & 0.536 & -0.166 \\
\hline Internship & 0.647 & 0.447 & 0.200 \\
\hline Legal Aspects of Aviation & 0.751 & 0.505 & 0.246 \\
\hline National Airspace Systems & 0.809 & 0.809 & 0.000 \\
\hline Professional Development & 0.874 & 0.831 & -0.043 \\
\hline Work Center Management & 1.044 & 0.894 & -0.150 \\
\hline
\end{tabular}

Reduction in average standard deviation indicated stability of consensus. The combination of standard deviation reduction and less than a $15 \%$ change in survey means augers of stability of consensus among airline industry respondents.

\section{Airline Executive Response Distribution}

Table 3 denotes industry respondent Survey 2 rankings for each curricular statement by ranking ranges of: inclusionary, exclusionary and uncertain/diverse. 
Table 3

Survey 2 Response Distribution of SIUC Aviation Curriculum

\begin{tabular}{|l|c|}
\hline Exclusionary Curriculum Statements & Survey 2 Group Mean \\
\hline Airport Planning & 2.445 \\
General Aviation Operations & 2.107 \\
National Airspace System & 1.893 \\
\hline Uncertain/Diverse Curriculum Statements & Survey 2 Group Mean \\
\hline Airport Management & 3.364 \\
Application of Technical Information & 2.636 \\
Basic Air Traffic Control & 3.818 \\
Professional Development & 2.909 \\
\hline Inclusionary Curriculum Statements & 4.727 \\
\hline Airline Management & 4.091 \\
Airline Internship & 4.273 \\
Aviation Safety Management & 4.364 \\
Aviation Industry Regulations & 4.455 \\
Aviation Maintenance Management & 4.455 \\
Aviation Labor Relations & 4.000 \\
Current Issues in Aviation Management & 4.273 \\
Data Interpretation & 4.273 \\
Fiscal Aspects of Aviation Management & 4.364 \\
Legal Aspects of Aviation & 4.000 \\
Work Center Management & \\
\hline
\end{tabular}

Distribution of the airline executive responses related to SIUC curriculum is pyramidal, with more statements identified for inclusion as educational requirements for a career in airline management than for either exclusion or uncertainty. Of the eighteen curriculum statements, $61.11 \%$ were ranked for inclusion, $16.67 \%$ for exclusion and $22.22 \%$ fell within the uncertain category.

\section{Analysis of Airline Industry Rated CAA Curriculum}

\section{Consensus Stability}

Analysis of airline industry respondent mean stability indicated one curriculum statement, General Aviation Management, with Survey 2 ratings identical to Survey 1 . The highest percentage change occurred in Air Transportation, experiencing a shift of $+12.36 \%$. Other curriculum statements with high percentage changes were Aviation History $(-0.53 \%)$, Marketing $(+8.45 \%)$ and Accounting I (+8.00\%).

Two of the eighteen curriculum statements, or $11.1 \%$, of data showed a lower mean. Fifteen Survey 2 responses (83.3\%) increased their mean. The average percent change for all curriculum statements from Survey 1 to Survey 2 was $+3.68 \%$, well within the predetermined $15 \%$ stability level. Thus, mean stability was achieved. Table 4 data shows mean stability ratings of airline respondents for CAA recommended aviation curriculum. 
Table 4

Airline Mean Comparisons of CAA Guideline Curriculum

\begin{tabular}{|l|c|c|c|}
\hline \multicolumn{1}{|c|}{ Topic } & Survey I & Survey II & $\%$ \\
\hline Accounting I & Mean & Mean & Change \\
\hline Air Cargo Management & 3.125 & 3.375 & $8.00 \%$ \\
\hline Air Transportation & 4.000 & 4.042 & $1.04 \%$ \\
\hline Airport Management & 3.708 & 4.167 & $12.36 \%$ \\
\hline Aviation History & 2.125 & 2.000 & $-5.88 \%$ \\
\hline Aviation Legislation & 1.583 & 1.417 & $-10.53 \%$ \\
\hline Business Law & 4.000 & 4.042 & $1.04 \%$ \\
\hline Data Interpretation & 4.208 & 4.292 & $1.96 \%$ \\
\hline $\begin{array}{l}\text { General Aviation } \\
\text { Management }\end{array}$ & 3.125 & 3.333 & $6.67 \%$ \\
\hline International Aviation & 1.792 & 1.792 & $0.00 \%$ \\
\hline Macroeconomics & 4.417 & 4.583 & $3.77 \%$ \\
\hline Management I \& II & 4.083 & 4.125 & $1.02 \%$ \\
\hline Marketing & 3.125 & 3.208 & $2.67 \%$ \\
\hline Microeconomics & 2.950 & 3.206 & $8.45 \%$ \\
\hline
\end{tabular}

Analysis of airline industry responses related to CAA guideline curriculum standard deviation stability indicated two curriculum statements, Aviation History and General Aviation Management, with no standard deviation movement between Survey 1 and Survey 2 . The largest change in standard deviation occurred with Accounting I curriculum statement, with a change of $(-14.470)$. Other curriculum statements with large changes in standard deviation were International Aviation (-13.710), Management I \& II (-13.430) and Data Interpretation (-9.27).

Average standard deviations for all curriculum statements decreased from (.677) in Survey 1 , to (.625) in Survey 2, a decrease of (.052). The data in Table 5 shows standard deviation stability ratings for airline industry respondents as they relate to CAA guideline curriculum. 
Table 5

Airline Executive Standard Deviation Comparisons For CAA Curriculum

\begin{tabular}{|l|c|c|c|}
\hline & Survey I & Survey II & \\
\hline \multicolumn{1}{|c|}{ Topic } & Std. Dev. & $\underline{\text { Std. Dev }}$ & Difference \\
\hline Accounting I & 0.881 & 0.753 & -14.470 \\
\hline Air Cargo Management & 0.577 & 0.538 & -6.740 \\
\hline Air Transportation & 0.676 & 0.624 & -7.710 \\
\hline Airport Management & 0.725 & 0.707 & -2.510 \\
\hline Aviation History & 0.493 & 0.493 & 0.000 \\
\hline Aviation Legislation & 0.707 & 0.676 & -4.440 \\
\hline Business Law & 0.644 & 0.611 & -5.150 \\
\hline Data Interpretation & 0.881 & 0.799 & -9.270 \\
\hline General Aviation & 0.644 & 0.644 & 0.000 \\
\hline Management & & & \\
\hline International Aviation & 0.571 & 0.493 & -13.710 \\
\hline Macroeconomics & 0.493 & 0.439 & -10.96 \\
\hline Management I \& II & 0.880 & 0.763 & -13.430 \\
\hline Marketing & 0.676 & 0.644 & -4.670 \\
\hline Microeconomics & 0.633 & 0.577 & -8.830 \\
\hline
\end{tabular}

As with the SIUC Aviation Management curriculum, reduction in average standard deviation indicated stability of consensus. Based on the combination of standard deviation reduction and less than 15\% change in the means between Survey 1 and Survey 2, stability of consensus was affirmed.

\section{Airline Industry Response Distribution}

Table 6 indicates the airline industry respondent Survey 2 rankings for each curriculum statement by ranking range; inclusionary, exclusionary and uncertain/diverse. 
Table 6

Survey 2 Response Distribution of CAA Guideline Curriculum

\begin{tabular}{|l|c|}
\hline Exclusionary Curriculum Statements & Survey 2 Group Mean \\
\hline Airport Management & 2.000 \\
Aviation History & 1.416 \\
General Aviation Management & 1.791 \\
\hline Uncertain/Diverse Curriculum Statements & Survey 2 Group Mean \\
\hline Accounting I & 3.375 \\
Data Interpretation & 3.333 \\
Management I \& li & 3.208 \\
Marketing & 3.206 \\
\hline Inclusionary Curriculum Statements & Survey Group Mean \\
\hline Air Cargo Management & 4.042 \\
Air Transportation & 4.167 \\
Aviation Legislation & 4.042 \\
Business Law & 4.292 \\
International Aviation & 4.583 \\
Macroeconomics & 4.125 \\
Microeconomics & 4.375 \\
\hline
\end{tabular}

Distribution of the airline executive's responses related to CAA curriculum is also pyramidal. More statements were identified as necessary for a career in airline management than for either exclusion or uncertainty. Of the fourteen curriculum statements, $50.00 \%$ fell in the inclusion category; $28.58 \%$ fell in the uncertain category and $21.42 \%$ were selected for exclusion.

\section{Conclusion}

Based on Kaps (1995), response distribution indicating similar stability and consensus among like subject matter in areas of inclusion, exclusion and questionable curriculum content are valid comparisons. Therefore, rather than redirect this study's focus to the similarity of excluded and uncertain topics, only those capable of inclusion as educational requirements for a career in airline management are considered.

Table 7, below, indicates those curriculum statements demonstrating statistically stable inclusion consensus. 
Table 7

SIUC \& CAA Curriculum Inclusionary Ratings

\begin{tabular}{|l|l|l|l|}
\hline \multicolumn{1}{|c|}{ SIUC } & Mean & \multicolumn{1}{c|}{$\begin{array}{c}\text { CAA Recommended } \\
\text { Courses }\end{array}$} & Mean \\
\hline Airline Management & 4.727 & Air Cargo Management & 4.042 \\
Airline Internship & 4.091 & Air Transportation & 4.167 \\
Aviation Safety Management & 4.273 & Aviation Legislation & 4.042 \\
Aviation Industry Regulations & 4.364 & Business Law & 4.292 \\
Aviation Maintenance Management & 4.455 & International Aviation & 4.583 \\
Aviation Labor Relations & 4.455 & Macroeconomics & 4.125 \\
Current Issues in Aviation & 4.000 & Microeconomics & 4.375 \\
Management & 4.273 & & \\
Data Interpretation & 4.273 & & \\
Fiscal Aspects of Aviation & 4.364 & & \\
Management & 4.000 & & \\
Legal Aspects of Aviation & & & \\
Work Center Management & & & \\
\hline
\end{tabular}

\section{Recommendations and Suggestions}

Based on the emerging consensus related to SIUC's curriculum and CAA's suggested aviation content, educational institutions considering incorporation of an airline management component should consider the adoption of inclusionary curricular statements identified in this study. The educational requirements indicated in this study are unique and specific enough to warrant such consideration. These findings reflect the current needs of an industry in a constant state of flux. As education must mirror such change, adaptation to industry needs is essential.

\section{References}

Adamski, J. J., \& Doyle, T. J. (1993). Introduction to the aviation regulatory process. Westland, MI: Hayden McNeil Publishing, Inc., p.vi.

Ary, D. et al. (1985). Sunvey research. New York: Holt-Rinehart, p. 357.

Best, J. W., \& Kahn, J. V. (1986). Research in education (5th ed). Englewood Cliffs, NJ: Prentice-Hall.

Balaraman, S., \& Venkatakrishnan, K. S (1980, January). Identifying engineering educational goals and priorities for the future: An experiment with the Delphi technique. Higher Education, p. 261.

Clason, D. L., \& Dormody, T. J. (1994). Analyzing data measured by individual Likerttype items. Journal of Agricultural Education, 35, p. 31-35

Concordia University (1993). International aviation degree programme. Montreal, Quebec, Canada: Author

Council on Aviation Accreditation (1990, December). Accreditation standards manual. Opelika, AL: Author.

Dajani, J., Sincoff, M., \& Talley, W. (1979). Stability and agreement criteria for the termination of Delphi studies. Technological Forecasting and Social Change, p. 13, 83-90. 
Dalkey, N.C., et al. (1972). Studies in the quality of life: Delphi and decision making. Lexington, MS. D. C. Heath and Company.

Helmer, O. (1966). The use of the delphi technique in problems of educational innovations. Rand No. P-3499. Santa Monica, CA: Rand Corporation. Sage.

Helmer, O. (1983). Looking forward: A guide to future research. Beverly Hills, CA;

Johnson, J., \& Lehrer, H. (1995). Doctoral degree in aviation. .Unpublished manuscript.

Kaps, R. W. (1995). Perceptions of aviation professionals and aviation educators concerning industry suggested curriculum content for a non-engineering aviation doctoral degree. Dissertation Abstracts International, 96-1979.

Kaufmann, R. A., \& English, F. W. (1979). Needs assessment: Concept and application. Englewood Cliffs, NJ: Educational Technology Publications

Leide, G. (1977). Expert judgments as evaluation data. In A. Lewy (ed.) Handbook of curriculum evaluation. New York: UNESCO. Psychology.

Likert, R. (1932). A technique for the measurement of attitudes. New York: Archives of

Miller, D. C. (1970). Handbook of research design and social measurement, 2d ed. New York: David McKay Company, Inc.

Pratt, D. (1980). Curriculum design and development. New York: Harcourt Brace.

Rojewski, J. W. (1990). Research priorities in vocational special needs: A Delphi approach. Unpublished doctoral dissertation, University of Nebraska, Lincoln, NE. IL.

Undergraduate catalog (1995). Southern Illinois University at Carbondale, Carbondale,

Volk, K. (January, 1993). Curriculum development using the Delphi techniques. The Technology Teacher, p. 35-36. 173-184.

World aviation directory (Summer 1994). Washington, DC, McGraw Hill, p. 119-170, 